
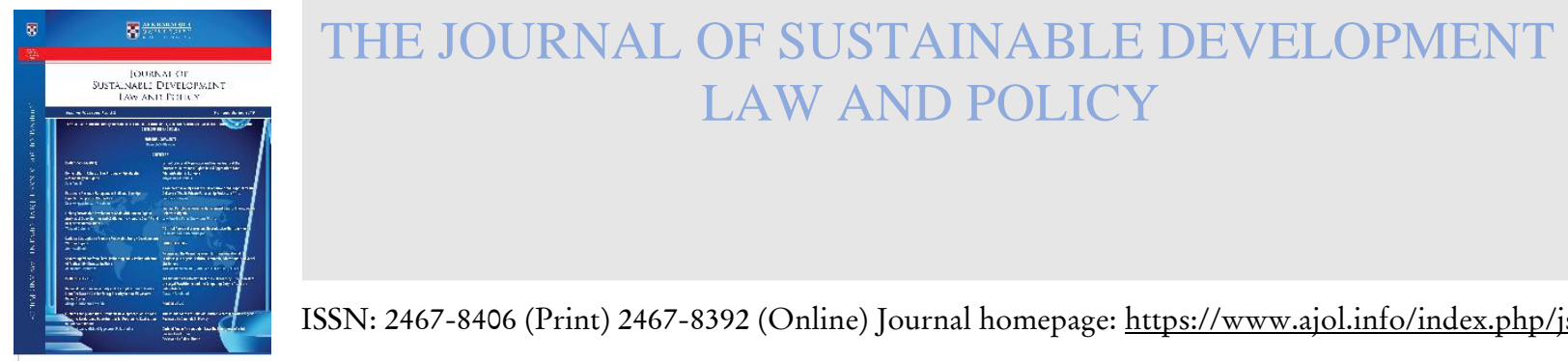

ISSN: 2467-8406 (Print) 2467-8392 (Online) Journal homepage: https://www.ajol.info/index.php/jsdlp

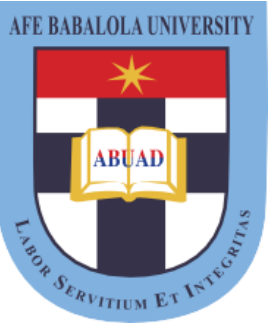

\title{
Should Countries Fire Sell their Oil \& Gas Assets? Addressing the Mis-conceptions Surrounding the Continued Role of Fossil Fuels in the Energy Transition Era
}

\section{Victoria R Nalule, Xiaoyi (Shawn) MU}

To cite this article: Victoria R Nalule, Xiaoyi (Shawn) MU (2020) Should Countries Fire Sell Their Oil \& Gas Assets? Addressing the Mis-Conceptions Surrounding the Continued Role of Fossil Fuels in the Energy Transition Era, The Journal of Sustainable Development, Law and Policy, 11:2, 432-440,

To link to this article: https://dx.doi.org/10.4314/jsdlp.v11i2.7

Full Terms \& Conditions of access and use can be found at https://www.ajol.info/index.php/jsdlp 


\title{
Should Countries Fire Sell their Oil \& Gas Assets? Addressing the Mis-Conceptions Surrounding the Continued Role of Fossil Fuels in the Energy Transition Era
}

\author{
Victoria R Nalule,* Xiaoyi (Shawn) MU**
}

(Received 09 October 2020; final version received 20 October 2020)

Access to modern energy such as electricity is key in the economic development of any country, and yet over 600 million people remain with no access to electricity in developing countries. It is true that both renewable energy and fossil fuels are key in the achievement of the United Nations Sustainable Development (UN SDG) Goal 7 and Goal 1 on energy access and poverty eradication respectively. However, the current global efforts to transition to a low carbon economy, and tackle climate change as stipulated in the SDG 13 and the 2015 Paris Agreement, have created a lot of tension on fossil fuel developments in recent years.

This commentary article is presented as a question and answer session aimed at addressing the misconceptions surrounding the achievement of SDG 7 and SDG 13 in this energy transition era. The paper is of interest to oil producing countries. The article follows the various questions raised by policymakers during an online seminar delivered by both the authors entitled, 'Fossil Fuels in the Energy Transition Era'.

Keywords: Energy Access; Climate Change; Energy Transitions; clean energy technology: Sustainable Development

\section{INTRODUCTION}

There have been various initiatives at the national, regional and international level to ensure the achievement of the United Nations' Sustainable Energy for All and the associated Sustainable Development Goal (SDG) 7. SDG 7 aims to ensure access to energy to the over 1 billion people who do not have access to reliable energy. ${ }^{1}$ Despite various efforts, the

* Victoria R. Nalule holds a PhD in International Energy Law and Policy from the Centre for Energy, Petroleum and Mineral Law and Policy (CEPMLP), University of Dundee. She is currently working on the DFID-funded Extractives Hub project in the UK as a Research Fellow. She is also the founder and Executive Director of the African Energy and Minerals Management Initiative (AEMI).

* Dr. Xiaoyi (Shawn) Mu is a Reader in Energy Economics at the Centre for Energy, Petroleum and Mineral Law and Policy (CEPMLP), the University of Dundee. He earned his Ph.D. in economics from the 
challenge of energy access persists especially in developing countries, where majority of people are still relying on traditional forms of energy such as charcoal and firewood for cooking and lighting. The challenge was initially being escalated due to the growing energy demand resulting from geometric population growth; rise in urbanisation and industrialisation; technology gaps; oil price volatility and reduced levels of finance for energy projects; as well as rising impacts of climate change on energy infrastructure. ${ }^{2}$ This situation has currently been exacerbated by the outbreak of the Coronavirus Disease 2019 (COVID-19), which has resulted to significant disruptions to global energy markets across the world, hence forcing many fossil fuels companies into bankruptcy. ${ }^{3}$ The impact of the COVID-19 has also emphasized the crucial role of renewables. There are various issues to be addressed with respect to the issue of energy access, energy security and the current pandemic. ${ }^{4}$ However, the aim of this commentary paper is to address some of the misconceptions surrounding the continued role of fossil fuels in the energy transition era. The paper provides a simplified analysis on the key questions facing the achievement of both SDG 7 and SDG 13 on energy access and climate change respectively. Presented in form of questions, the paper is made

University of Oklahoma in 2006 and Bachelor's degree in economics from Renmin University of China in 1994.

1 United Nations, 2015

2 Olawuyi DS. Can MENA extractive industries support the global energy transition? Current opportunities and future directions. The Extra -ctive Industries and Society. 2020 Mar 4.

3 Some of these companies include, Pacific Exploration \& Production 5.3 billion in debt: Samson Resources -- $\$ 4.3$ billion in debt; Ultra Petroleum - \$3.9 billion in debt; Sabine Oil \& Gas -- \$2.9 billion; Ene-rgy XXI $\$ 2.8$ billion. There are many other companies in huge debts. For further information, please see, Christopher Helman, 'The 15 Bi-ggest Oil Bankruptcies-so far' (Forbes, 9 May 2020), https://www. forbes.com/ sites/christopherhelman/2016/05/09/the-15-biggest-oil-ba-nkruptciesso-far/\#61e1f4c67ff9. Last accessed on $15^{\text {th }}$ October 2020.

4 For a detailed discussion, see, Nalule VR. Energy Access Challenges in the COVID 19 crisis: Is there a future for Extractives in the Energy Transitions era? Extractives Hub, CEPMLP, University of Dundee. 2020 May. Can be accessed at, Energy Access Challenges in the COVID 19 crisis: Is there a future for Extractives in the Energy Transitions era? 
up of 5 sections this being the introduction. Section 2 gives a clear definition of energy transition and addresses the question as to whether countries should fire sell their oil and gas assets; Section 3 addresses the social and economic impacts associated with energy transitions, and also examines how countries can reconcile fossil fuel developments and climate change action; Section 4 spotlights the different reactions of countries with respect to fossil fuel developments in this energy transition era; Section 5 gives the concluding remarks.

\section{DOES ENERGY TRANSITION IMPLY A TOTAL BAN ON FOSSIL FUELS? SHOULD COUNTRIES FIRE SELL THEIR OIL AND GAS ASSETS?}

Energy transition does not mean a total ban on fossil fuels. In simple terms, energy transition refers to a shift from fossil fuels to cleaner forms of energy. Energy transition is a progressive process; however, some experts have used the term to shame countries that still desire to develop their fossil fuels. ${ }^{5}$ Although some parts of the globe such as Europe have made significant efforts to decarbonise the energy sector by among others deploying renewable energy, energy efficiency technologies, smart grids, smart meters and electric vehicles: ${ }^{6}$ other regions especially rural areas in developing countries are still progressing from traditional biomass, although there are various renewable energy projects in these countries. ${ }^{7}$

Taking stock of the above, a wholesome transition away from fossil fuels is not expected. For example, it is often said that our world has transitioned from "coal age" to "oil age" decades ago. Yet, coal still accounted for more than a quarter

5 For a full discussion on 'Energy Progression', see, Nalule VR. How to Respond to Energy Transitions in Africa: Introducing the Energy Pro -gression Dialogue. In: Nalule V.R. (eds) Energy Transitions and the Future of the African Energy Sector 2021 (pp. 3-35). Palgrave Macmillan, Cham.

6 Leal-Arcas R, Peykova M, Nalule V, Kara P. Decarbonizing the energy sector. J. Animal \& Nat. Resource L.. 2019;15:173.

7 Supra note 5. See also, Nalule VR. Transitioning to a Low Carbon Economy: Is Africa Ready to Bid Farewell to Fossil Fuels?. In The Palgrave Handbook of Managing Fossil Fuels and Energy Transitions 2020 (pp. 261-286). Palgrave Macmillan, Cham. 
of global energy supply in 2019 and the world used two and half times of coal in 2019 than in 1973. ${ }^{8}$ For most developed countries, traditional biomass (wood, crop waste, or charcoal) has lost its prominent role in the global energy mix since the industrial revolution. ${ }^{9}$ Yet, the world used $60 \%$ more biomass in 2019 than did in 1860. Additionally, we note that many developing countries such as those in Asia and Africa, are still struggling to transition from traditional energy to modern energy. For instance, given the social roles of women in various Sub-Sahara African (SSA) countries, such as cooking and other domestic work, women spend a lot of time collecting biomass fuels such as firewood: Estimates indicate that women spend on average 1.4 hours a day collecting fuel wood and four hours for cooking. ${ }^{10}$ This in essence highlights the essential role of access to modern energy in not only achieving SDG 1 on poverty eradication, but also SDG 5 on gender equality.

Taking into consideration the above, countries should not fire sell their oil and gas assets. Additionally, finances in these projects should not be reduced, but rather cleaner forms of technology should be embraced. What is desirable is for countries to invest in both fossil fuels and renewables. Nevertheless, given the global efforts to tackle climate change as stipulated in the 2015 Paris Agreement, coupled with public pressure and shaming; there have been developments in some countries aimed at totally banning fossil fuel dependency. In Norway, for instance, there has been a halt in fossil fuel investments. In June 2020, the Norwegian parliament recommended that the Sovereign wealth fund sells off more than $\$ 10$ billion of stocks in companies related to fossil fuels. ${ }^{11}$

$8 \mathrm{Mu}$ and Jena, Comparison of Outlooks and Implications for Energy Transition" in The Global Energy Transition: Law, Policy and Economics for Energy in the $21^{\text {st }}$ Century, edited by Cameron, P., Mu, X., Roeben, V. Hart, 2020.

9 ibid

10 Nalule VR. Energy Poverty and Access Challenges in Sub-Saharan Africa: The Role of Regionalism. Springer; 2018 Aug 27.

11 David Nikel, 'Norway Wealth Fund to dumb fossil fuels stock' (Forbes, $12^{\text {th }}$ June 2020). Can be accessed at, https://www.forbes.com/sites /davidnikel/2019/06/12/norway-wealthfund-to-dump-fossil-fuel-stock 
Besides Norway, in November 2019, The European Investment Bank (EIB), approved a policy to ban funding for oil, gas and coal projects at the end of 2021. Although gas projects could still be funded, as long as they are utilizing clean technologies such as carbon capture and storage, combining heat and power generation, or mixing in renewable gases with the fossil natural gas. ${ }^{12}$ These are just a few examples of the various developments in the energy sector, which negatively and directly have a financial impact on fossil fuel investments. The above notwithstanding, the fact that oil has a higher energy density compared to other fuels and relatively moderate carbon emission rates makes it difficult to be replaced for certain uses, particularly in transportation. ${ }^{13}$ Even in the most dramatic scenarios projected by BP (2020), due to depletion, significant investment is still required to meet the global demand for oil and gas for several decades to come. So, there is no need to rush to sell your oil and gas assets.

\section{WHAT ARE THE SOCIAL AND ECONOMIC IMPACTS ASSOCIATED WITH ENERGY TRANSITIONS, ESPECIALLY FOR HYDROCARBON- RICH COUNTRIES?}

By background, we note that Goal 7 of the United Nations Sustainable Developmental Goals (SDG) advocates access to affordable and clean energy for all. ${ }^{14}$ Access to modern forms of energy such as electricity is crucial to addressing other global challenges such as poverty, famine and gender inequality: ${ }^{15}$ reliable data shows that three billion people more than $40 \%$ of the world population - are still relying on

s-worth-billions-in-environmentalmove/\#4dbb5c9748a3. Last accessed 11 September 2020

12 BBC, 'European Investment Bank drops fossil fuel funding' (BBC News, $14^{\text {th }}$ November 2019). Can be accessed at, https://www.bbc.co. $\mathrm{uk} /$ news/business-50427873. Last accessed $15^{\text {th }}$ October 2020

13 There is substantial growth in electric vehicles. However, significant challenges remain, particularly in terms of driving range, charging time, and charging infrastructure. For detailed analysis, please see Mu and Jena (2020).

14 United Nations Sustainable Development Goals, 2015.

15 Supra Note 8. 
polluting and unhealthy fuels for cooking. ${ }^{16}$ With this data in mind, we must agree that a wholesome transition is likely to have both positive and negative impacts. Positively, more investments will be directed to renewable energy projects, and this will also present employment opportunities. However, this will also imply a decline in investments in fossil fuels. Below, a brief of the negative impacts:

\subsection{Social impacts- Access to electricity}

A wholesome transition is likely to escalate energy access challenges. Socially, many people lack access to electricity and are still reliant on traditional energy such as charcoal and firewood, as such the transition should focus on ensuring that these people progress from charcoal to other forms of modern energy such as electricity (which can be generated using both renewables and fossil fuels). ${ }^{17}$ The focus for developing countries in Asia and Africa, therefore is access to electricity. Electricity in its natural form tends to appear as lighting and static, the technological advancement has enabled primary sources of energy such as coal, nuclear power, running water and of late renewable energy sources to provide this electricity. In this respect, for a country with more than $80 \%$ of the population lacking electricity, the focus will not entirely be on the kind of primary energy used to provide this electricity, but rather on ensuring that people shift from wood and biomass usage. Fossil fuels are also still essential for the urbanisation and industrialisation of many developing countries. As such, a wholesome transition will negatively affect developing countries that are counting on their fossil fuels for economic development.

\subsection{Economic impacts}

The economic impact is likely to be felt by producing countries such as Nigeria, Angola and Algeria that are massively dependent on hydrocarbons for their budgets.

16 United Nations Development Programme: SDG 7 on Clean Energy. Can be accessed at https://www.undp.org/content/undp/en/home/sus tainable-development-goals/goal-7-affordable-and-clean-energy.html.

17 Supra Note 5 
Whereas it might appear that extractive industries are key in tackling poverty and ensuring economic development, there have been instances where countries endowed with massive natural resources grow slower than resource-poor countries and faced with political instability. This is what scholars have termed as the resource curse, and it is attributed mostly due to corruption, poor governance and ineffective institutions. ${ }^{18}$ Nevertheless, if well managed, these resources can contribute to the economic development of countries as was the case in Norway and Botswana. The United States, Canada and Australia are also resource-rich countries. The challenge for resource-rich countries is therefore how to harness the windfall revenues from fossil fuel development and contribute to sustainable growth. ${ }^{19}$

\subsection{How do we reconcile fossil fuel development and efforts to address climate change?}

It is true, fossil fuels are the main contributor to climate change as it produces around 60 per cent of greenhouse gases. Additionally, the UN Intergovernmental Panel on Climate Change (IPCC) issued a warning in 2018 that humanity had just twelve years to limit global warming to below $2{ }^{\circ} \mathrm{C} .{ }^{20}$ However, focus should be put on how to utilise these resources in a sustainable manner. Although fossil fuels are associated with climate change impacts, cleaner and more efficient production and utilization methods can reduce emissions from fossil fuel use. By investing in clean technologies such as carbon capture and storage, combining heat and power generation, or mixing in renewable gases with the fossil natural gas, the high carbon footprints associated with fossil fuel production and use can be significantly reduced. ${ }^{21}$

18 Olawuyi DS. Extractives Industry Law in Africa (Springer; 2018) 1-25.

19 For a detailed discussion on the impact of natural resources on economic growth, see Mu (2019, Chapter 1) and van der Ploeg (2011).

20 Intergovernmental Panel on Climate Change (IPCC). 2018. Global Wa rming of $1.5^{\circ} \mathrm{C}-\mathrm{A}$ Special Report. https://www.ipcc.ch/sr15/.

21 Olawuyi DS. 'Can MENA extractive industries support the global energy transition? Current opportunities and future directions' (2020) The Extractive Industries and Society. 


\section{HOW ARE COUNTRIES REACTING TO FOSSIL FUEL DEVELOPMENTS IN THIS ENERGY TRANSITION ERA?}

They are mixed signals with respect to fossil fuel developments as summarised below:

\subsection{More investments in renewables}

Huge investments in renewable energy projects are evident in different developing countries. Kenya for instance has one major wind farm, Ngong Hills Wind Farm, located in Ngong, Kajiado County. It produces around 5.1 MW of electricity. It is owned by Kenya Electricity Generating Company (KenGen) and cost KES 1.6 billion (US\$18 million) to construct. There are various renewable energy project in different countries, which cannot be exhausted in this short paper.

\subsection{Steady investments in fossil fuel infrastructure}

With the new oil discoveries in countries such as Uganda and Kenya, there have been initiatives to invest in more fossil fuel infrastructure. For instance, Uganda has proven crude oil reserves of 6.5 billion barrels, about 2.2 billion of which is recoverable. The country recently, on the $10^{\text {th }}$ of September 2020, concluded and signed with Total, a Host Government Agreement (HGA) for the East Africa Crude Oil pipeline (EACOP) project. ${ }^{22}$ Further, with the high anticipation to benefit from fossil fuels, Uganda and Tanzania represented by the heads of State, finally signed an agreement for the construction of a 1,445 km (898 miles) East Africa Crude Oil Pipeline. This $\$ 3.5 \mathrm{bn}$ project is intended to connect Uganda's oil fields to Tanzania's port of Tanga. ${ }^{23}$

22 Uganda New Vision: Uganda, Total sign key oil pipeline agreement. Can be accessed at https://www.newvision.co.ug/news/1526795/ugandatotal-sign-key-oil-pipeline-agreement. Last accessed $12^{\text {th }}$ September 2020

23 BBC, 'Uganda and Tanzania sign \$3.5bn oil pipeline deal' (BBC News, September 2020). Can be accessed at https://www.bbc.co.uk /news/ world-africa-54137090. Last accessed on the $15^{\text {th }}$ of September 2020. 
Gas infrastructure are evident in different oil-rich countries. For instance, on $30^{\text {th }}$ June 2020, President Muhammadu Buhari launched a \$2.6 billion gas pipeline project in Nigeria. The $614-\mathrm{km}$ long pipeline will run from Ajaokuta to Kano under the auspices of Nigerian National Petroleum Corporation (NNPC). ${ }^{24}$

All the above developments point to the keen interest hydrocarbon-rich countries have in utilising natural gas resources to meet the energy demand in the region. Besides ensuring energy security, fossil fuels, specifically natural gas, has been recognized as an environmentally preferable product (EPP) for a low carbon transition. Basically, "environmentally preferable" refers to products or services that have a lesser or reduced effect on human health and the environment when compared with competing products or services that serve the same purpose. ${ }^{25}$

\section{CONCLUSION}

As highlighted above, hydrocarbon rich countries should invest more in clean technologies to utilise these resources. Development of fossil fuels doesn't imply that renewables should not be utilized, as such countries should also invest more in clean energy such as wind and solar. Good governance, transparency and accountability are also key in utilising natural resource to ensure that revenues from fossil fuels can finance renewable energy projects. Additionally, mineral rich countries should take note of the increasing role of critical minerals such as cobalt and lithium in the energy transition.

24 The Guardian: Unlocking Nigeria's economic possibilities via gas infrastrcture (2020). Can be accessed at, https://guardian.ng/energy/unloc king-nigerias-economic-possibilities-via-gas-infrastructure/. Last accessed on $10^{\text {th }}$ September 2020

${ }^{25}$ UNCTAD, 1995. Environmental Preferable Products (EPPs) as a Trade Opportunity for Developing Countries, Report by UNCTAD Secretariat, UNCTAD/COM/70, Geneva. 